\title{
The Capture of Jerusalem by the Muslims in 634
}

https://doi.org/10.34739/his.2019.08.03

\begin{abstract}
The aim of this article is to show that there is an alternative way to reconstruct the Muslim conquest of Roman Levant, which is actually militarily more plausible than the current consensus view among historians.
\end{abstract}

Key words: Roman military, Byzantine military, Muslim military, Muslim Conquests, tactics, Battle of Yarmuk, Battle of Fihl, Battle of Ajdanayn, Jerusalem, Heraclius, Khalid b. Walid, Abu Bakr, Umar

\section{Background}

This article still takes the stance that there is an alternative way to reconstruct the Muslim conquest of the Roman Levant, which is actually militarily more plausible than the current consensus view among the historians. The following account proves that the ability of the Muslims to conquer Jerusalem in about 635-637 was based on two things: 1) the military blunders committed by the Romans; 2) the superb strategic and tactical skills of the Muslim leadership. The analysis will show that it was the Muslim military might and the way in which it was used that decided the fate of the city of Jerusalem. In the last resort, the ownership of the city depended and will in all probability always depend on the individual decisions taken by generals, officers and soldiers.

The evidence for the early stages of the Muslim conquest of Roman territory is controversial because the sources offer conflicting and confused evidence. The consensus view among modern historians is that the Muslim conquest began in earnest with the battle of Ajdanayn in 634 after which they conquered Damascus and that the Romans then launched a counter attack which failed at the battle of Yarmuk in the summer of 636 after which followed up the Muslim conquests of Syria, Palestine and Jerusalem. This study, however, takes up a different view and suggests that the battle of Ajdanayn has been confused with the battle of Yarmuk in the Arabic sources and that the actual battle of Ajdanayn took place only after the battle of Yarmuk. This study also suggests that some of the East Roman sources

* ORCID iD 0000-0002-6084-0234. ilkkasyvanne@yahoo.com; The writing and presenting of this article was been made possible by the ASMEA Travel Grant 2018. 
have confused the battle of Gabitha/al-Jahiya with the battle of Yarmuk ${ }^{1}$. The view adopted here on the basis of military probability is that, with some emendations, which take into account the doublets, Tabari's account (mainly the one base on Sayf) has preserved for us the genuine sequence of events ${ }^{2}$. The following account begins with the major campaign that Abu Bakr launched to conquer the Roman Syria and Palestine in 634.

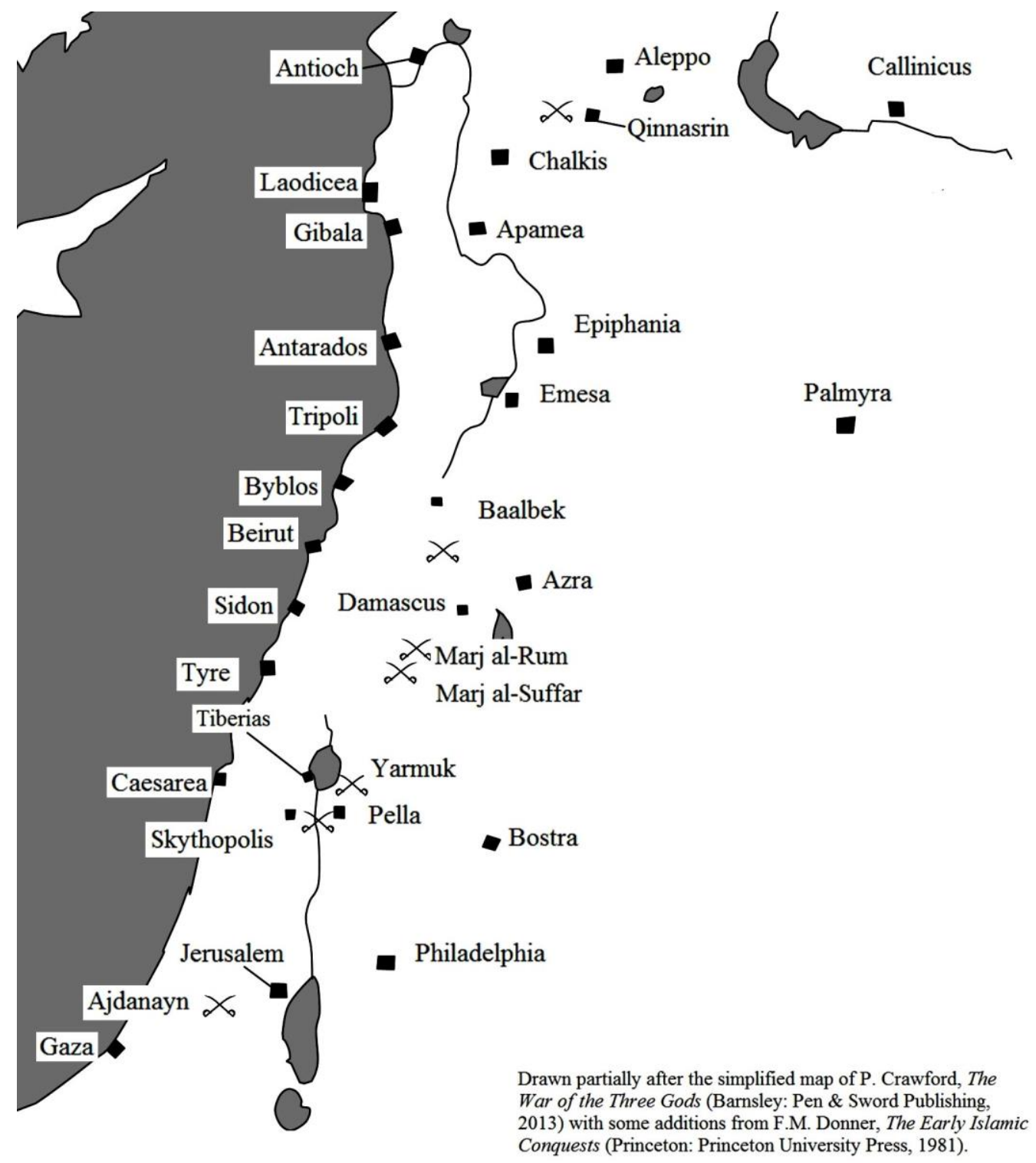

Fig. 1. Map of the Principat Locations Mentioned in the Text. C SYVÄNNE 2018

\footnotetext{
${ }^{1}$ The confusion is evident in Theophanes AM 6125.

2 Tabarī 2079-2127, 2346-2350. The battle of Ajdanayn (i.2124-2127) is a doublet of Yarmuk while the 2398-2402 represents the genuine event.
} 


\section{The Beginning of the Major Offensive against the Romans in 634}

According to Țabarī, Abu Bakr began his main campaign against Roman Palestine and Syria in March 634. He planned to conquer the area with a multipronged invasion. Amr b. al-Asi was dispatched to Aqabah with the goal of advancing into Palestine. Yazid b Abi Sufyan, Abu Ubaydah b. al-Jarrab and Shurahbil b. Hasanah were dispatched to the plateau east of river Jordan with the purpose of invading Syria. Khalid b. Said was dispatched to Tayma. When the Romans leant of the concentration of forces, they levied forces of Arabic origin from Syria against them. Abu Bakr ordered Khalid to attack. The Arabs duly deserted to Khalid's side and embraced Islam. It is very likely that this resulted from the Roman refusal to pay the traditional payments to their Arabic allies. The adoption of this policy was very unwise indeed. After the above desertion, the patrikios/patricius Bahan/Vahan marched against Khalid, but was defeated. Khalid, however, appears to have suffered significant number of casualties because he then asked Abu Bakr to dispatch reinforcements. Since all of Khalid's men wanted to be replaced, Abu Bakr did that by dispatching al-Walid with orders to conquer the area around Tiberias. At the same time as this happened Abu Bakr dispatched reinforcements to Amr who was ordered to conquer Palestine. Khalid used the replacement army for an immediate offensive. Vahan feigned flight and retreated towards Damascus and then ambushed Khalid at Marj al-Suffar. Vahan's wings surrounded the Arabs at the same time as he turned against them. Khalid's son Said b. Khalid was killed, and when the news was brought to Khalid, he fled. Ikrimah, however, fought an effective rearguard action and was able to put a stop to the pursuit. Khalid b. Said was duly relieved of his command ${ }^{3}$.

After this, Abu Bakr ordered the four other generals to begin their invasion so that each of them was given chief cities of Syria as objectives while Ikrimah with the remaining forces of Khalid was to serve as a covering force for them. Amr and Abu Ubaydah marched along the coastal route. Yazid and Shurahbil marched along the Tabuk road. When the emperor Heraclius was informed of this, he marched to Emesa (Hims/Homs) where he prepared the soldiers for combat with drills and exercises. Tabari claims that Heraclius dispatched his full brother Theodore with $90,000(9,000$ ?) men against Amr. Theodore's force was also supported by a "rear guard" which marched along up to Thaniyyat Jilliq (village of Jillin in southern Hawran in Syria) ${ }^{4}$ where it encamped. Did this 'rear guard' oppose Ikrimah? Jurjah b. Tawdhura (George son of Theodore) was sent against Yazid and they encamped

\footnotetext{
${ }^{3}$ Tabarī 2078-2086; Theophanes AM 6123 (AD 630-631). The dating in Theophanes is several years off. Theophanes (AM 6124/ AD 631/2) includes also a minor incident not mentioned by Tabari. According to Theophanes, in the year when Abu Bakr dispatched four generals against the Romans (i.e. in 634), Sergius marched from Caesarea with 300 soldiers against the Arabs who had advanced to Gaza with the result that he and his men were killed.

${ }^{4}$ Identification of the locale by Blankinship/Ṭabarī, 84 .
} 
opposite each other. Al-Duraqis (possibly Theodore the sakellarios/Theodore Trithyrios) opposed Shurahbil, and al-Fiqar b. Nastus (bikarios/vicarius son of Nastus) with 60,000 (6,000?) men opposing Abu Ubaydah. The Muslims were frightened because the Romans outnumbered them. According to the first version preserved by Țabarī, the four generals had 21,000 and Ikrimah 6,000 men, but at a later point Tabarī includes the claim that the four generals had 27,000 men plus 3,000 survivors of Khalid b. Said and 6,000 men of Ikrimah for a grand total of 36,000 men. However, if the size of the Roman force was about 40,000 men ${ }^{5}$, which is likely, the numerical difference was not great, but still significant enough to cause worry so that Abu Bakr ordered them to unite their forces ${ }^{6}$. When Heraclius learnt of this, he ordered his patrikioi to unite their forces. Theodore was to be the overall commander, George in command of the vanguard, Vahan and al-Duraqis were in charge of the wings and vicarius in charge of mobilization ${ }^{7}$ (harb, in this case probably meaning logistics and/or the camp with infantry), but this actually describes the situation after the arrival of Vahan with reinforcements. He also sent them orders to choose such a battleground in which the place was easy to supply. The location was also to have a wide space for the pursuit of the enemy, but with very little room for retreat. The Strategikon recommended this kind of battlefield when the commander feared the prospect of attack against his rear because the enemy possessed very sizable cavalry forces or outnumbered the Roman cavalry ${ }^{8}$.

However, I would suggest that in this case we should interpret this instruction in another way because the Muslims had fewer horsemen than the Romans. In my opinion, the selection of a battlefield which prevented an easy flight proves that the morale in the Roman army was not high. Heraclius' intention was to force the men to fight because the army was placed in such a locale that prevented an easy flight. The four likeliest reasons for the poor morale would be the religious disputes within the Church, the persecution of the religious minorities, the failing mental and physical health of the emperor, and especially the endemic difficulties in paying the salaries of the soldiers ${ }^{9}$. The important point here is that it was the Roman side which chose the battlefield and not the Muslims as usually claimed. The Roman leadership beginning with the emperor was clearly not up to the task.

\footnotetext{
${ }^{5}$ On the basis of Theophanes (AM 6125-6) it is easy to see that before the reinforcements brought by Vahan and Theodore the sakellarios the Romans had about 40,000 men.

${ }^{6}$ Tabari 2085-2088, 2090-2091. It is possible to think that in the larger version Ikrimah's 6,000 men and the 3,000 survivors of Khalid b. Said have been counted twice, once among the 27,000 men and then again as separate forces, but I have here accepted the larger version because it explains better why the Romans chose not to attack.

7 This is Blankinships' translation in Țabarī, 85.

${ }^{8}$ Tabarī 2088-2089; Strategikon, 11.2.99ff., 12.2.23.1-7. See also the perceptive comments of KAEGI (1992: 123-125).

${ }^{9}$ The problems facing Heraclius before the main Muslim attack are analyzed by KAEGI (2003: 192-228). It is obvious that many of these affected the morale. The most important of these is likely to have been the difficulty of paying salaries which is mentioned by Theophanes (AM 6123).
} 
The poor morale was not the only problem facing the Romans. None of the extant sources give any details that would suggest that the Roman infantry would have fought successfully after 599. The extant texts prove that Heraclius achieved all of his victories in pitched battles against the Persians with his cavalry, which means that Heraclius had used his infantry only for the holding of the camp, protection of the rear of the cavalry forces and for sieges after the year 622 . There could be two reasons for this. Heraclius was either prejudiced against infantry forces just like Belisarius had been, or the Roman infantry was not really combat ready and Heraclius knew this. Either way, this was disastrous for the Romans who now faced an enemy which relied on the combined arms concept to win the battles ${ }^{10}$. If the emperor did not trust his infantry to be able to face the Muslims, he should not have used it all, but he should have relied on the cavalry to defeat the enemy. And how the cavalry should have been used when it faced an enemy force which employed the combined arms concept? Its superior numbers should have been used for mobile guerrilla warfare with the goal of denying access to food and water, but this was not to be because the Romans sought a decisive battle.

\section{The Battle of Jabiya-Yarmuk in 634}

When the Romans had then pitched their marching camp close to al-Waqusah/Yaqusa, they used the wadi behind them as a trench and built a fortified marching camp to the east of it. The location of the camp is not known and has been variously placed by historians. This is a question that only battlefield archaeology can solve. All that we know for certain is that the Romans had both the Wadi Ruqqah (the rear of the camp) and al-Waqusah behind them. The likeliest location is probably just in front of the bridge leading across the Wadi Ruqqah. See the map. The Muslims in their turn united their forces and marched to the scene where they built a camp opposite the Romans. Amr was particularly elated because the Romans had placed themselves in a trap. This resulted in stalemate which lasted from April 6 until July 2, 634/6. Initially, the Romans were unable to even leave their camp, but after June 3 they managed to force the Muslims to such a distance that they could start a period of prolonged skirmishing which lasted until July 2. Both sides felt unable to commit their army to a full battle with the result that both asked reinforcements from their rulers. Heraclius dispatched Vahan and Theodore the sakellarios with reinforcements to the scene ${ }^{11}$ while Abu Bakr most famously sent Khalid $\mathrm{b}$. Walid from Iraq to the rescue presumably with orders to take the overall command. Țabarî’s text claims

\footnotetext{
${ }^{10}$ SYVÄNNE 2004: 451-456, 478-489.

${ }^{11}$ It is probable that the sending of reinforcements to the Romans at the request of Theodore, the brother of Heraclius, has been confused in Theophanes (AM 6126) who claims that it was Vahan who urged the sakellarios to bring reinforcements. It is more than likely that these two men brought reinforcements to the scene together.
} 
that the Romans had after this 80,000 cavalry and 80,000 infantry, but on the basis of the Roman sources the likelier figures are 40,000 cavalry and 40,000 infantry, which was still a major effort. The Roman army, however, was very imbalanced as a fighting force and the inability of the infantry and cavalry to cooperate made the situation even worse. Vahan had dispatched deacons, monks, and priests ahead of time to encourage the men to fight. This suggests a very poor morale because the men clearly needed extra effort from the religious establishment to fight ${ }^{12}$.

According to another version of the battle preserved in Tabarī, the Roman army present at the battle of Yarmuk consisted of the regulars, allied Arabs (Lakhm, Judham, Balqayn, Bali, Amila and tribes affiliated with Qudaah and Ghassan) and allied Armenians. The overall size of the force was 100,000 men so that it included 12,000 Armenians under Jarajah and 12,000 Arabs under Jabalah b, al-Ayham al-Ghassani. The overall commander was al-Saqalar (sacellarius), the eunuch of Heraclius. The figures for the Armenians and Arabs can be considered reliable and so can the overall size of 100,000 men if one includes in it the servants ${ }^{13}$.

The Muslims in their turn had 27,000 men in four divisions and an additional 3,000 men drawn from the remnants of Khalid b. Said's forces which were divided between Muawiyah and Shurahbil. Ikrimah possessed an additional 6,000 men who had acted as a rear guard for Khalid b. Said. Therefore the overall size of the Muslim army before the arrival of Khalid $b$. Walid was 36,000 men $^{14}$. Khalid b. Walid brought additional 10,000 men, which were urgently needed in a situation in which the Romans were reinforced by 40,000 men. The overall size of the Muslim army was therefore 46,000 men, most of which consisted of infantry ${ }^{15}$.

The Romans attacked immediately after Vahan's reinforcements had arrived. The Muslims were in trouble thanks to their numerical disadvantage, but the last minute arrival of Khalid with his reinforcements and the fact that he assumed the command of the army changed the situation so that the Muslims forced the Romans to flee back to their camp. I would suggest that we should connect this with the incident mentioned by Ibn Ishaq according to which the Romans managed to penetrate into the Muslim camp where even the women fought with swords ${ }^{16}$. The Romans stayed inside their camp for a month from July 3 until the month of Jumada al-Akhirah (August 2-30). During this period the priests, deacons, and monks did their best to uplift the morale until the soldiers were finally ready to attempt another attack - the morale was clearly not high. Theophanes dates the battle to have

\footnotetext{
${ }^{12}$ Țabarī 2088-2089; Theophanes AM 6125-6126.

13 Tabarī $2347 \mathrm{ff}$.

14 The four divisions can be equated with the late Roman divisions in which the different infantry and cavalry units were combined to create temporary old style legions with ca. 4,000-6,000 infantry (an infantry meros/legio) and 800-1,600 cavalry. For the development of this type of regiment, see SYVÄNNE 2015-2017.

${ }^{15}$ Tabarī 2090ff.

16 Ṭabarī 2347.
} 
taken place on Tuesday July 23, which would date the battle to the year 636 . Considering the many problems with Theophanes' text, I would not put too much trust on the date but would rather follow the very detailed account of Tabari in this case. This would place the battles of Yarmuk and al-Qadisiyyah to the year 634-635, but obviously the dating is still uncertain ${ }^{17}$.

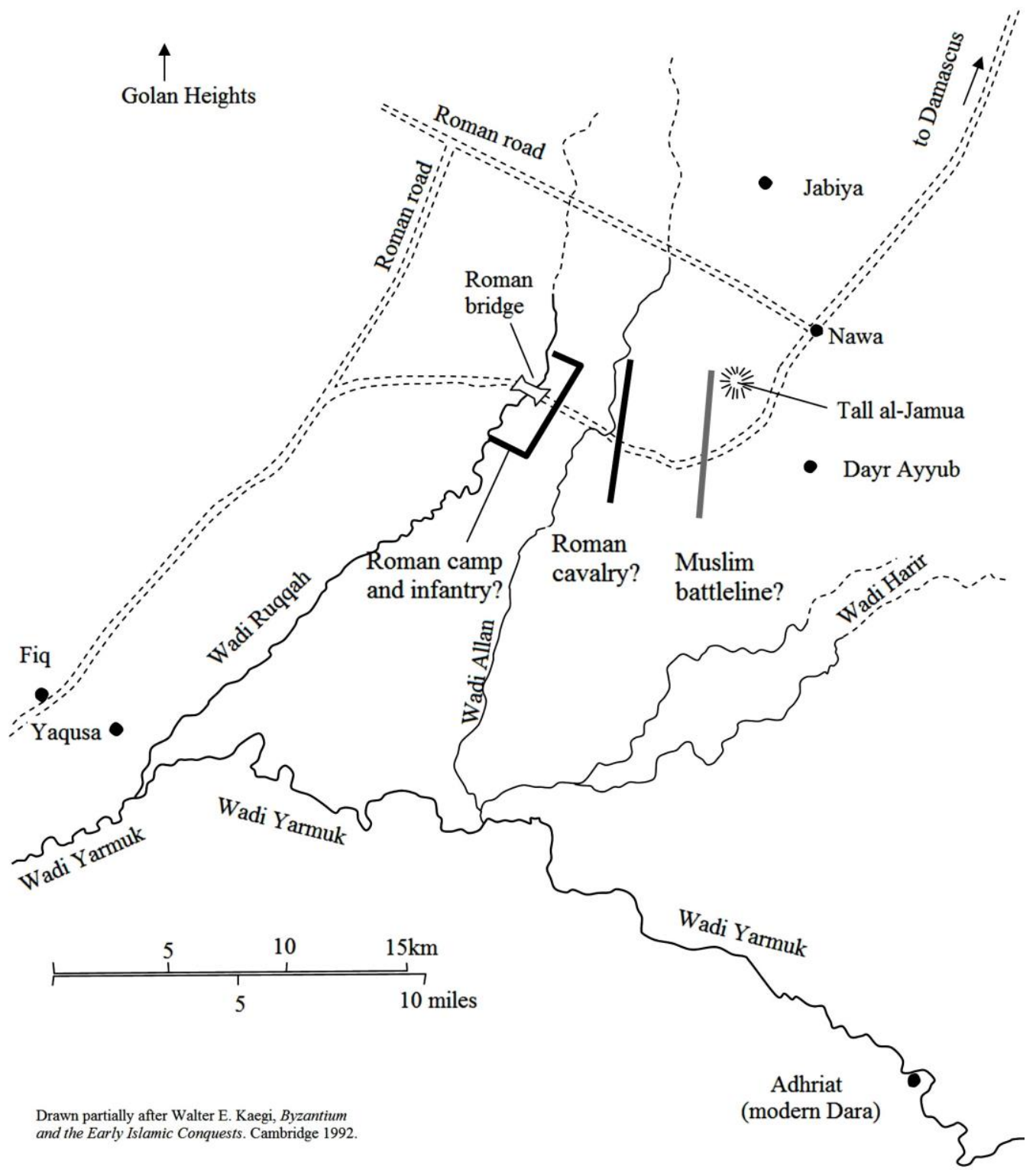

Fig. 2. The Topographical Map of the Battle of Yarmuk. C SYVÄNNE 2019

\footnotetext{
${ }^{17}$ Țabarī 2091-2092; Theophanes AM 6126. Țabarī’s account is also confused because he later (2389ff.) jumps to the year 636-637 so that it is also possible that the Muslim invasion started in 635 .
} 

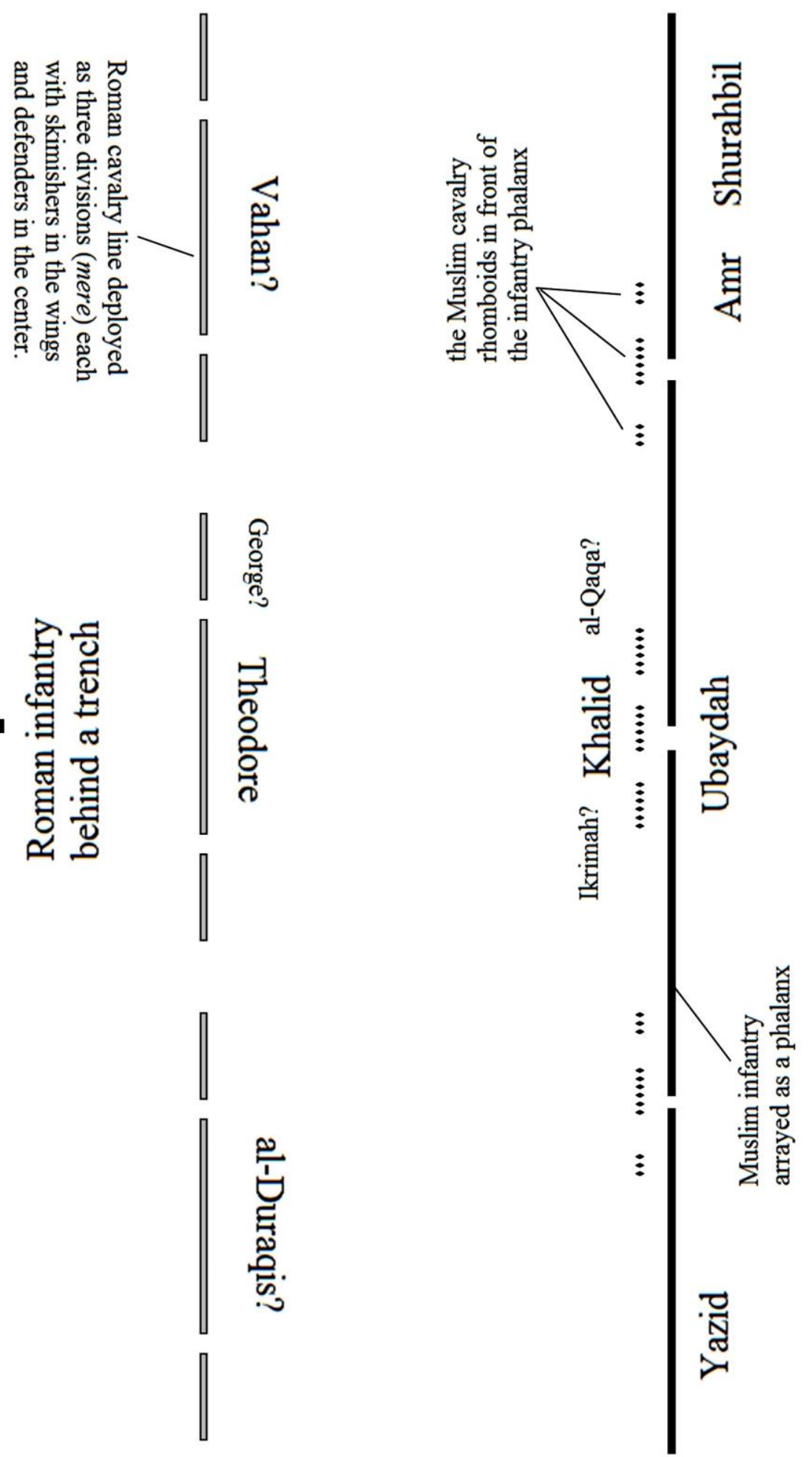

Fig. 3. Battle of Yarmuk. The Likely Battle Formations. (C) SYVÄNNE 2018 
The only information that we have of the Roman combat formation is: the cavalry was posted in front; it was such that the Muslims had never before seen it; infantry was behind trenches which probably means the marching camp. The problem with this is that the Strategikon instructed the general not to involve many cavalry in infantry battles and in this case we are witnessing precisely this. The Strategikon has two alternative arrays in which the cavalry was posted in front: 1) Two cavalry lines posted in front with an infantry phalanx behind; 2) Three cavalry divisions posted in front as a single line with infantry phalanx two to three miles behind. The problem with these is that all of these were designed to be used against cavalry and not against the combined arms tactics employed by the Muslims, but this is precisely what happened now. The Romans posted their cavalry in advance of their infantry. The likeliest of these is the second version because that would explain better why Khalid was able to separate the Roman cavalry from the infantry ${ }^{18}$.

We are on a more secure ground with the Muslim battle formation. According to Tabari, Khalid b. Walid arrayed the Muslim army in such a manner that they had never used before. Khalid arrayed the cavalry in front of the infantry phalanx so that these were divided into $36-40$ or $38^{19}$ units called kardus (pl. karadis). In other words, these were deployed as 128 men strong rhomboids ${ }^{20}$. This formation was particularly useful for skirmishing style combat because the rhombus had fronts facing all directions while it also had four points which could be used to penetrate enemy formations. The right and left wings consisted both of 10 karadis so that each wing had ca. 1,280 horsemen in front of their infantry. The center consisted of 18 karadis for a total of 2,304 horsemen. The total number of cavalry would therefore have been 4,864 plus the officers and supernumeraries. This would leave 41,136 footmen with the implication that the vast majority of the Muslim army consisted of infantry. However, in light of the previous and later descriptions of combat, I would suggest that a very significant portion of these footmen or rather that all of them would have been cavalry or camel mounted infantry that was just dismounted for this battle. Khalid placed Abu Ubaydah in command of the center, Amr in charge of the right wing with Shurahbil, and the left wing under Yazid ${ }^{21}$.

Khalid began the battle by ordering the two wings of the center under Ikrimah and al-Qaqa forward. Each of them appears to have had six karadis so that the middle of the center had the remaining six karadis. This proves that each of the three cavalry divisions was further divided into left, center, and right just like in the Roman army.

\footnotetext{
${ }^{18}$ Țabarī 2092ff.; Strategikon 12.1.1-6, 12.2.13, 12.2.23.

19 Tabarī includes two variants.

${ }^{20}$ Blankinship (Ṭabarī, p.90 n.493) considers the karadis in this case to be an anachronism because Ṭabarī later (ii.1941, 1944) specifically states that Marwan b. Muhammad started their use in the eight century. I disagree. By this time the rhombus array had been used in this area for a period ca. 900 years and it is quite obvious that it was also familiar to the Arabs who had served in the Roman and Parthian-Sasanian armies which employed it.

${ }^{21}$ Ṭabarī 2092-2096.
} 
The cavalry units attacked and then pursued each other, which means that the different cavalry units attacked and retreated as the situation dictated in a large scale skirmish. In the midst of this combat a rider arrived from Medina with the news that Abu Bakr had died and that Abu Ubaydah has been nominated as overall commander by Umar. Khalid placed the message in his quiver and kept the news to himself so that the soldiers would not become disordered. Abu Ubaydah, who was with Khalid, appears to have agreed with this decision. The placing of the message in quiver and the use of the rhombus array prove that the Muslim cavalry was using mounted archery, which is actually not surprising because the rhombus was the favorite unit order of the Armenian and Parthian mounted archers. The details given suggest that some of the Roman cavalry units left their formation to pursue the Muslim units who then performed an about turn at the same time as another Muslim unit charged against the pursuers after which the Romans retreated back to their lines so that one of the Roman units in reserve attacked against the Muslim units and the same thing was repeated again and again ${ }^{22}$.

At that moment George from the Roman center approached to parley with Khalid. As a result of this meeting George deserted to the Muslim side and Khalid took him to his tent. We do not know the nationality of George, but it is possible that he was an Arab because an account based on Ibn Ishaq suggests that when the Muslims marched against the Romans the Lakhm and Judham deserted to their side. According to Tabarī, the Romans attacked when George deserted because they believed that George was attacking the enemy. The Romans forced the Muslims to leave their positions with the exception of Ikrimah and al-Harith b. Hisham ${ }^{23}$ who were in the center. This means that with the exception of the two commanders and units under them, the Muslim rhomboids were all forced to flee behind their infantry which is not surprising in light of the massive numerical superiority of the Roman cavalry. The Muslim infantry, however, naturally held its ground and forced the Roman cavalry back. This is not surprising because the Muslim infantry appears to have been deployed as a pike phalanx akin to the earlier Macedonian one but with the exception that it had a rank of men armed with short swords placed in the front ${ }^{24}$. This addition made the array also very suitable for close range combat. The presence of the Muslim rhomboids in the midst of the already weakened Roman cavalry center ${ }^{25}$ naturally disordered its array. Khalid and George then led their men forward against the disordered Roman cavalry while the other Muslim rhomboids regrouped behind the infantry and charged. The Romans were forced to retreat back to their positions ${ }^{26}$.

\footnotetext{
22 Tabarī 2092ff. ; Byzantine Interpolation of Aelian J1-2, 92-106.

${ }^{23} \mathrm{He}$ is not mentioned among the commanders of rhomboids so he may be one of the missing karadis in the list which claims that there were up to 40 of those.

${ }^{24}$ SYVÄNNE 2004: 405-6.

25 The desertion of George weakened it.

${ }^{26}$ Ṭabarī 2092-2099 (esp. 2099).
} 
Khalid, however, did not stop his attack but ordered the Muslim cavalry to charge into the Roman cavalry formation which was in the midst of reforming after their retreat. The Muslims employed the swords at close quarters fighting with great effectiveness. According to Tabarī, Khalid and George kept on attacking the enemy. The combat lasted from before the sunrise (the above-mentioned beginning of the attack) until the sun was setting. The implication is that the Muslim rhomboids charged and retreated repeatedly and then performed the worship of Allah with a sign when this was possible during the maneuvering. This also implies that the Muslims changed their horses during this combat so that they were able to continue the relentless harassment. The Roman leadership was clearly incompetent because they could not prevent the Muslims from doing this despite their numerical advantage. It was then that George was killed. I would suggest that it was also then that the Lakhm and Judham fled to the neighboring villages thanks to the severity of fighting which is mentioned by Ibn Ishaq ${ }^{27}$.

By the end of the day the repeated attacks against the Roman cavalry and the desertion of George with the Arabs had weakened the Roman center enough for it to collapse. Khalid charged through it so that he isolated the Roman cavalry from its infantry support. This caused a widespread panic so that the Roman cavalry simply fled. Some of them panicked completely so that it was every man for himself while other units appear to have fled under the leadership of their commanders. When the Muslims realized that the Roman cavalry was attempting to flee, they opened up their ranks to allow them to pass through. The Roman cavalry then scattered throughout the country and desert. This means that the Muslim cavalry units simply moved to allow the Romans room to flee while the Muslim infantry performed the highly sophisticated combat maneuver called antistomos difalangia which was meant to be used in such situations in which the enemy cavalry wedge charged at a phalanx. The idea was to allow the enemy cavalry or elephants or camels or chariots to pass through the formation in an orderly manner. This formation could also be used to subject those who passed through it to a bombardment of missiles, but in this case the Muslims apparently rather allowed the Romans just to go as fast as they could because Khalid and the Muslims aimed to destroy the Roman infantry ${ }^{28}$.

After the Roman cavalry had abandoned their infantry to its own fate, Khalid and the Muslims advanced against the Roman infantry in its trench. The fact that the Roman infantry was protected by the trench actually bespeaks of its weak morale. Even if the morale of the infantry had been good at the beginning of the engagement, it was by now definitely low for two reasons. The distrust that the Roman leadership had showed towards the infantry had definitely lowered its morale, and the flight of the cavalry would have removed even the last shreds of their will to fight. Khalid

\footnotetext{
27 Ṭabarī 2092-2099 (esp. 2098-2099), 2348.

28 Țabarī 2099; Byzantine Interpolation of Aelian Dain E1-5.
} 
pushed the Roman infantry against al-Waqusah (probably Wadi Ruqqah) so that in the words of Tabari the bound men and others fell into it so that those who were bound pulled even those who would have wanted to fight so that one pulled ten with him. Tabari also states that 120,000 (80,000 bound and 40,000 unfettered) were plunged into al-Waqusah and killed besides those who had been killed in the battle between the cavalry and infantry. The bound men were undoubtedly the heavy-armed men using the tortoise formation while the unfettered were the lightly-armed. This should be interpreted so that the Romans lost 60,000 men of which 40,000 were infantry and 20,000 cavalry in addition to which there were the casualties suffered during the fighting and desertions. Vicarius (second-in-command hypostrategos), who had undoubtedly been in charge of the infantry, and the other Roman nobles resigned to their destiny and wrapped themselves in their mantles and sat down to be killed. Theodore fled to his brother Heraclius ${ }^{29}$. The Muslims lost 3,000 men including Ikrimah. After the battle had ended Abu Ubaydah assumed the command ${ }^{30}$. The loss of the Roman infantry sealed the fate of Roman Syria, Palestine and Arabia. Without infantry the Romans could not defeat the Muslims on the battlefield, and when the cities rather negotiated with the Muslims, it was impossible to defeat the Muslims with guerrilla warfare conducted by cavalry. The battle is a prime example of gross military incompetence. The Romans did not attempt to exploit their numerical advantage, but attacked head on as instructed by Heraclius.

\section{The Siege of Damascus and the Battle of Fihl (Pella) in August 634-February 635}

A significant portion of the surviving Roman cavalry appear to have fled southwards. It was because of this that Abu Ubaydah divided his forces into two divisions. He left Bashir b. Kab b. Ubayy al-Himyari with cavalry at Yarmuk to act as his rearguard, while he himself with most of the men pursued those who had fled northwards under Vahan. Ubaydah's goal was to take Damascus. When the news of the Roman regrouping at Pella was brought to Abu Ubaydah, he halted at Marj al-Suffar and sent a message to Umar regarding the situation. Umar's instructions were for Ubaydah to post shielding cavalry forces against the Romans at Pella, Palestine and Emesa while Ubaydah himself would attack Damascus ${ }^{31}$.

Ubaydah dispatched ten commanders each with five subordinate commanders against the Romans at Pella. The Roman response was to resort to the opening up

\footnotetext{
${ }^{29}$ One of the versions (Ṭabari 2104) claim that he was killed, but it is clear that this confuses two Theodores.

${ }^{30}$ Ṭabarī 2099-2104, 2347ff.

31 Țabarī 2144-2148. The battle of Fihl has usually been placed to take place after the so-called battle of Ajdanayn but this results from confusion of the two battles in the sources (different version in Tabarī 2145-2148).
} 
of the dams which created a muddy obstacle (presumably one of the rivers north of Pella) between the armies. The Muslim response was to contain the Roman threat from the opposite side of the river. Tabari claims that the size of the Roman force was 80,000 horsemen, but one may divide this figure with at least two or... four. If it really consisted of 20,000-40,000 horsemen again, it was a very significant effort by the Romans who would have collected for this most of their available forces in southern Palestine, Arabia and Egypt. As instructed, Ubaydah also posted Dhu al-Kala between Damascus and Emesa to act as a covering force, and another force under Alqamah b. Hakim and Masruq between Damascus and Palestine. Damascus was protected by the forces of Nastas b. Nasturus. Ubaydah put the city under a hard siege which lasted for seventy days. The Muslims used assaults, archery fire, and ballistae, but to no avail because the defenders expected to be relieved. Indeed, Heraclius dispatched a relief army possibly under Vahan from Emesa, but the Muslim shielding force under Dhu al-Kala forced them to a halt in front of him. When the defenders then realized that the reinforcements would be unable to reach the city, their morale collapsed. It was then that a child was born to the patrikios Nastus. Nastus duly held a celebration possibly in an effort to uplift the morale. When Khalid's scouts reported that the defenders were neglecting their posts, this was exploited by Khalid. Khalid and his men attacked the city at the strongest place because this was not expected. Khalid crossed the trench by using water-skins after which his men used rope ladders and lassoes to climb up to the wall. After this, they opened up the gate. Khalid's men poured in, but at the other gates the citizens negotiated a deal with the other Muslim commanders. This agreement stipulated that the soldiers and others who wanted were allowed to leave while those who remained would pay the jizyah-tax. When the news of this reached Vahan, he retreated back to Heraclius. It was then that Umar commanded Ubaydah to dispatch 10,000 men to Iraq against the Persians ${ }^{32}$.

Ubaydah and Umar both thought it was unwise to advance against Heraclius at Emesa while the rear was threatened by the concentration of Roman forces at Pella. Consequently, Ubaydah left Yazid with cavalry at Damascus and marched south. Yazid obtained the cities of Palmyra and Batanaea through surrender. Ubaydah dispatched Abu al-Awar to besiege the city of Tiberias. In the meanwhile Ubaydah advanced on the east side of the river Jordan to join forces with those who had already been sent against the Romans with the result that the Romans who were at Pella (Fihl) retreated across the river Jordan and then opened up the dams close to the city Skythopolis (Baysan) so that the river became a muddy obstacle between the two armies. Ubaydah encamped his army at Pella and sent a letter to Umar to ask for further instructions. However, before this happened, the Romans under their commander Saqallar b. Mikhraq (probably Theodore the sakellarios) attempted a surprise attack and crossed the river. The Muslims were prepared and in combat

${ }^{32}$ Ṭabarī 2146-2156. 
formation. The result was the hardest fought battle of the war which lasted until the Romans were disordered during the darkness of the second night ${ }^{33}$. The sakellarios and the second-in-command Nasturus were both killed with the result that the Romans fled. The Muslims gave chase but were initially unable to find them because they did not realize that the Romans would ride straight into the mud of the River Jordan. Once the Muslims realized where the Romans were, they butchered them. With the exception of a few lucky individuals the entire Roman army was annihilated ${ }^{34}$.
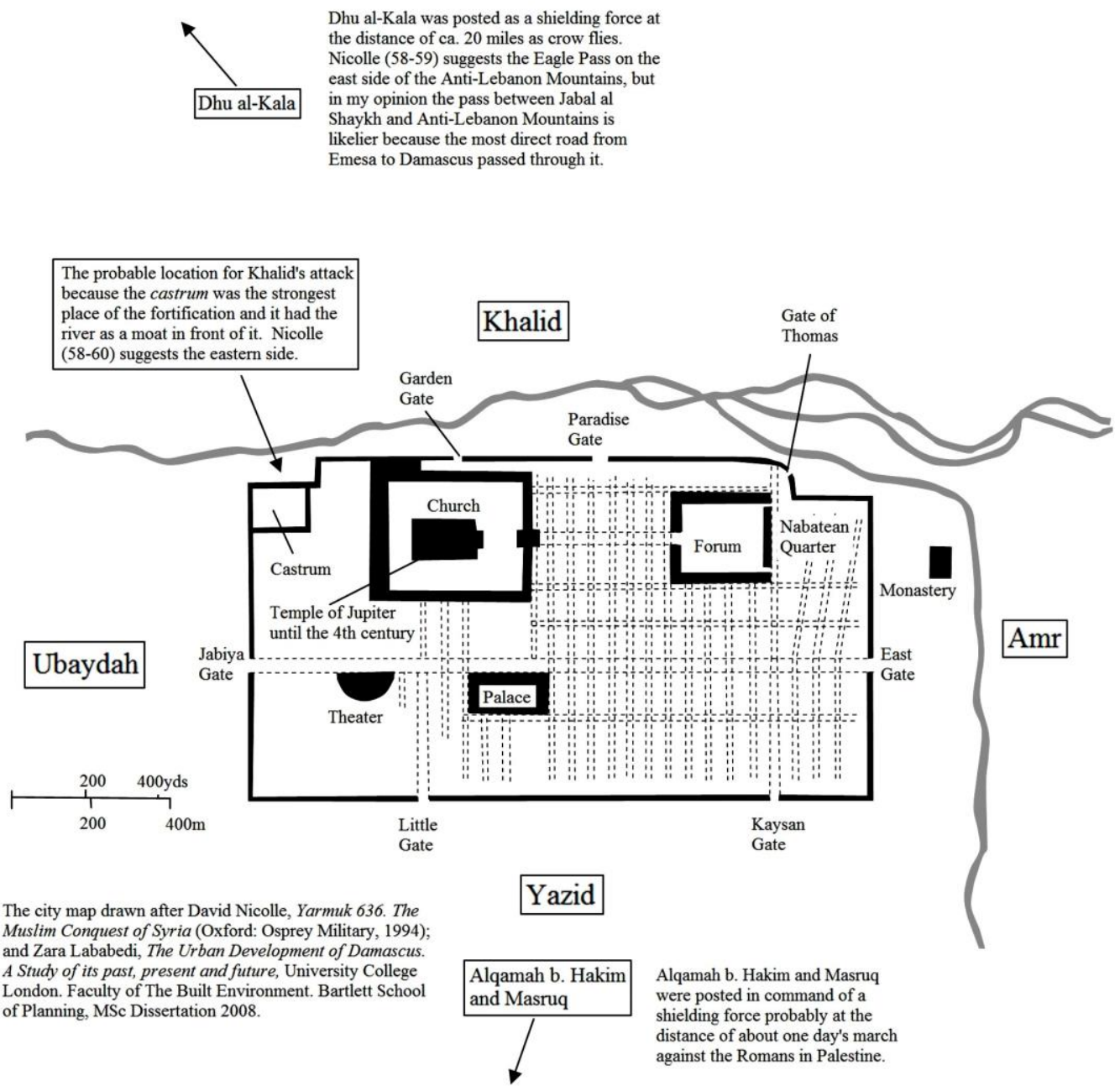

Fig. 4. Roman Damascus. (C) SYVÄNNE 2018

\footnotetext{
${ }^{33}$ The Muslims used the khat to enable them to withstand prolonged combat and were therefore able to outlast the Romans. See SYVÄNNE 2014.

${ }^{34}$ Tabarī 2150-2159, 2227-8, 2305, 2347, 2349-2350.
} 

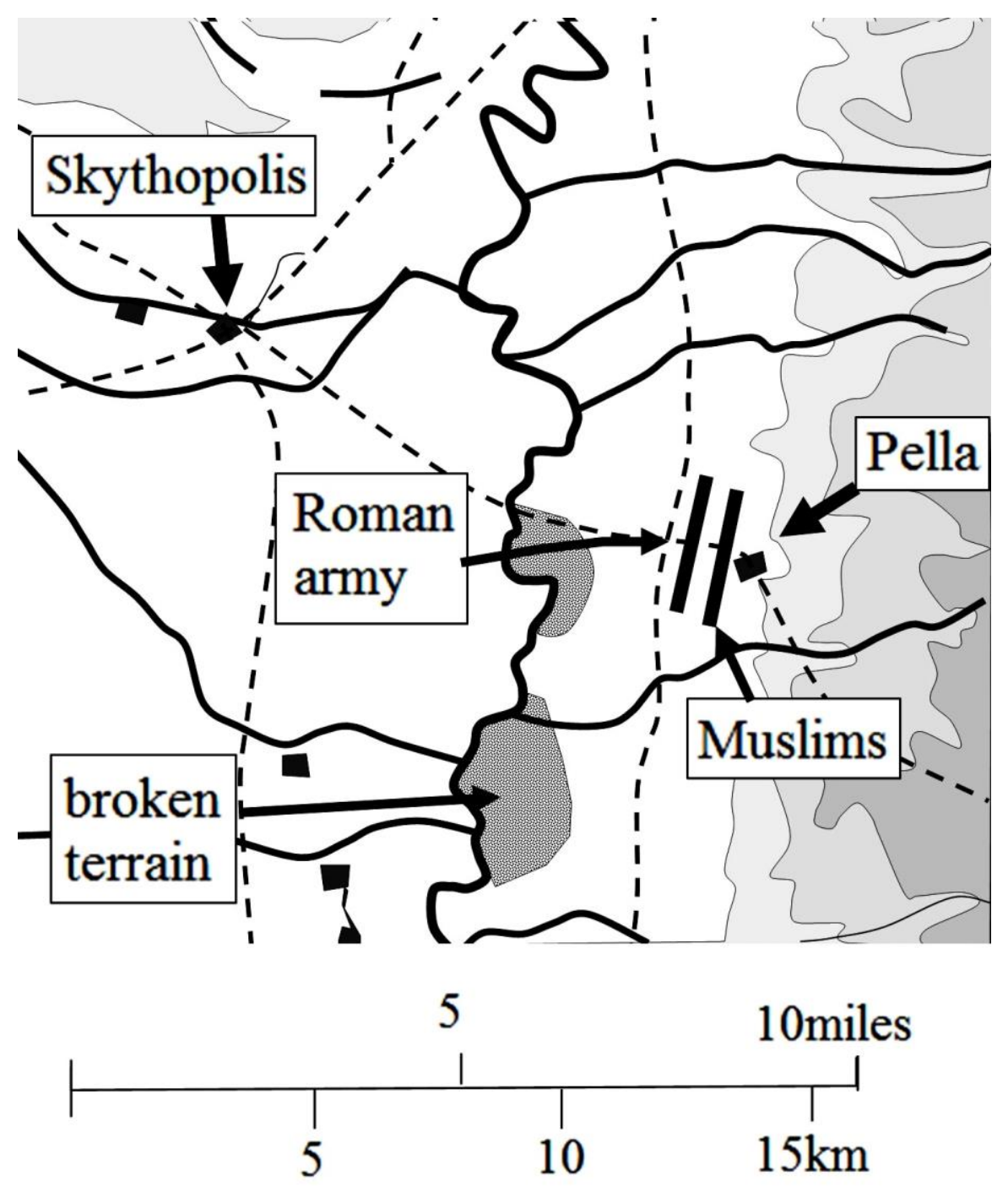

Fig. 5. Battle of Pihl/Pella. (C) SYVÄNNE 2018

The Battle of Marj al-Rum and Siege of Emesa in the winter $635^{35}$

Shurahbil and Amr were left behind to continue the conquest of Jordan, Palestine and Arabia, while Abu Ubaydah and Khalid b. Walid marched north against Heraclius in the city of Emesa. Ubaydah's idea was to surprise the Romans by continuing the operations in the middle of winter. En route they were joined by the cavalry forces of Bashir b. Kabb b. Ubayy al-Himyari who had been left at

${ }^{35}$ This chapter is based on Tabarī 2158-2159 and 2389ff. 
Yarmuk $^{36}$. When the news of the enemy advance was brought to Heraclius, he sent Theodore the patrikios against them. According to Tabarī, Theodore pitched a marching camp on the plain to the west of the city of Damascus - in truth south-west of Damascus. Shanas al-Rumi served as his second-in-command (hypostrategos). The Roman army consisted of cavalry, which on the basis of the text and composition of the force means that its purpose was to force a battle with the advancing Muslim army.

On the basis of this it is clear that the Romans were forced to rely solely on their cavalry against the combined forces of their Muslim enemy. This brings up the question why did Heraclius rely solely on his cavalry? Does this mean that he no longer had any combat ready infantry left and that he had to use whatever poor quality infantry he had for the defense of the cities and forts? Or, does this mean that Heraclius did not know how to use infantry or lacked confidence in its fighting ability? If Heraclius had adequate numbers of combat ready infantry left to engage the Muslims, his decision to rely solely on cavalry was an inexcusable military blunder. However, on the basis of the numbers of infantry lost at the battle of Yarmuk, it is quite probable that Heraclianus had lost so many footmen that he no longer had any meaningful numbers of combat ready infantry left. This would mean that the defeat at Yarmuk had already decided the outcome of the war for the next few years.

Abu Ubaydah attacked first the Roman cavalry who were under Shanas al-Rumi at Marj al-Rum. Tabarī states that the Romans were suffering from the effects of winter so that many of them were wounded. Shanas had the same number of horsemen as Theodore and his mission was to act as second-in-command for Theodore. In the context of period tactics, Shanas was therefore the hypostrategos whose place in the cavalry array was in the middle of the front line. This means that Shanas had been deployed in the front while Theodore was behind, but probably in such a manner that the two commanders guarded two different roads.

When Theodore failed to appear on the scene Shanas built a separate marching camp presumably close to the place of combat. My guess is that it was behind the river shown on the map. The facts that the Romans suffered many wounded during this first attack and Shanas built a separate camp mean three things: Firstly, Shanas had been defeated and presumably forced to retreat; Secondly, the Muslims had a combined force while Shanas had only cavalry, which made it next to impossible for the Romans to defeat the Muslims; Thirdly, Theodore failed to bring support to Shanas. In short, these two Roman commanders failed to cooperate and coordinate their actions in any meaningful manner. This alone would have sealed the fate of this Roman expedition.

${ }^{36}$ Ṭabarī 2105, 2154. 


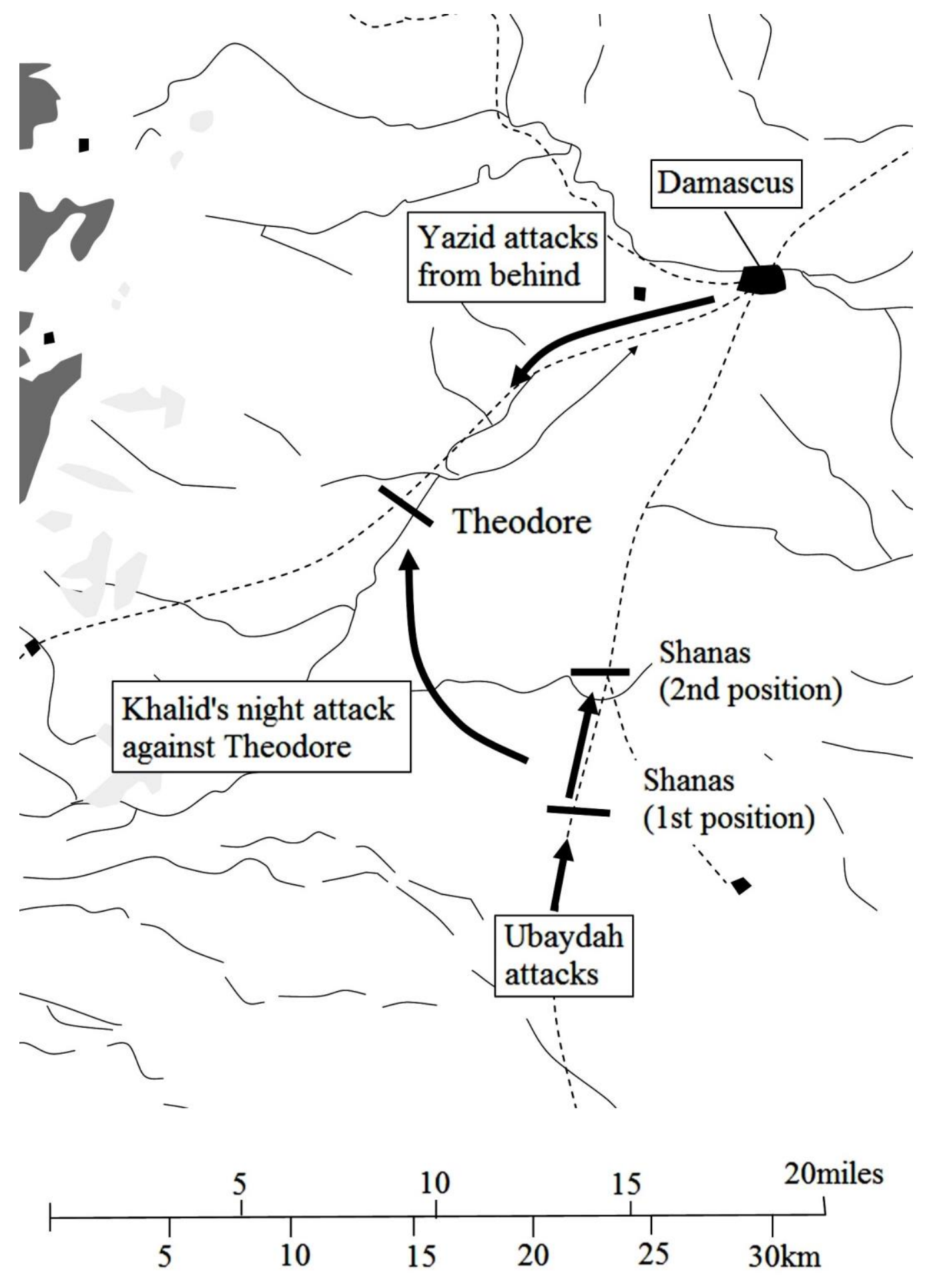

Fig. 6. Battle of Marj al-Rum. (C) SYVÄNNE 2018 
On top of this Theodore deserted Shanas in the middle of the night and marched towards Damascus. The reason for this appears to have been the fact that the Muslims turned their line, because Tabari states that Khalid was opposite Theodore while Abu Ubaydah was opposite Shanas. This could have happened only if Khalid had bypassed Shanas on the left and threatened Theodore from the flank with the result that Theodore fled north-east towards Damascus. The Muslims were therefore conducting a simultaneous night attack against both Roman camps, the move of which was detected but only with the result that the Roman disaster became even greater. The Roman commanders had clearly blundered by not joining their forces in the same camp - it is impossible to know what were the instructions given by Theodore to Shanas before the battle, but what is clear is that Shanas did not retreat to Theodore's camp and neither did Theodore join Shanas. Regardless of what the orders were, the main culprit for the defeat was obviously still the overall commander Theodore who should not have abandoned his second-in-command. The Muslim commanders agreed that Khalid would pursue Theodore with light cavalry while Abu Ubaydah attacked Shanas who was killed ${ }^{37}$. The Muslims had informed Yazid b. Abi Sufvan who had been left at Damascus with cavalry ${ }^{38}$ that Theodore would be fleeing towards him with the result that he arrayed his forces to blockade Theodore's route. Khalid reached the scene just when the two sides were fighting against each other with the result that the Romans were utterly crushed and Theodore killed. When Abu Ubaydah had also defeated his enemy, the Muslim victory was complete. Thanks to the fact that the Romans consisted of cavalry some of them were able to flee to Emesa. Abu Ubaydah pursued them up to there and Khalid b. Walid joined him soon there, and the city was placed under a siege.

Heraclius, however, had already fled and crossed the Euphrates into Mesopotamia so that he had a river between himself and the enemy. He stayed at al-Ruha so that he sometimes made threatening movements by moving out of the city in an effort to keep the enemy guessing where he intended to go. He also dispatched the dux of Emesa to take charge of the defense of the city. His orders were not to fight except during the cold days because it was winter and the Muslims would suffer because of this. The commander acted as instructed but the Muslims were not deterred despite the sufferings. The faith kept the men warm. Then when the spring came, there appears to have been an earthquake which caused the defenders to negotiate a surrender on the same terms as at Damascus. Consequently, the Muslims gained the city and the defenders were allowed to retreat ${ }^{39}$.

\footnotetext{
${ }^{37}$ Tabarī 2390.

${ }^{38}$ Țabarī 2156.

${ }^{39}$ Ṭabarī 2391-2393, 2395.

Page $\mid 54$
} 


\section{The Battle and Siege of Qinnasrin in $\mathbf{6 3 5}^{40}$}

Heraclius' measures to halt the Muslim advance had so far proved a failure and this trend continued. Abu Ubaydah dispatched Khalid b. Walid against the city of Qinnasrin which was located south of Aleppo. When Khalid had reached the populated area close to the city, the Romans under their commander Minas/Menas attacked him to save the city. According to Tabarī, this Minas was the greatest man after Heraclius, which probably means that he was the magister officiorum. It is clear that Heraclius must have dispatched him with the elite court troops to save the place. After all, even though the text does not state how many men Abu Ubaydah gave Khalid b. Walid, it is clear that his contingent cannot have been larger than about 7,000-10,000 men so that it could have seemed possible to attempt the relief with the small elite forces under the magister. The two fought a battle in the populated area with the result that Minas and all his men died. This probably means that Khalid had placed his men in an ambush inside the houses of the populated area. This would have negated the effects of the charge of the Roman elite cavalry on top of which these would have found themselves scattered among the houses and fields with no way out of the trap. This was first rate generalship. After this the people of this area sent a message to Khalid in which they stated that they were Arabs and that the enemy had forced them to serve against the Muslims and that they did not want to do this. Khalid accepted the excuse and continued his march against Qinnasrin. The people of Qinnasrin, however, fortified themselves against Khalid and asked for terms of surrender. Khalid agreed, but only with the condition that the city was destroyed, presumably meaning the walls, and so it happened. The city of Emesa suffered a similar fate.

In the meanwhile, Heraclius had learnt of what had happened to Minas. He decided to retreat to Arsanas (Shimhat), and when the Muslims reached al-Ruha, he fled to Constantinople. He had no other alternative. The Muslims attacked with two divisions. Khalid attacked from Syria while the Arabs of Mesopotamia attacked from the direction of Mosul (ancient Niniveh) along the corridor between the Euphrates and Tigris. Had Heraclius stayed in place, his route of retreat would have been cut off by Khalid's division. At the same time as this happened, Heraclius evacuated all the fortresses between Alexandretta and Tarsus, and had all the fortresses in the area destroyed, while his men conducted a guerrilla campaign against the invaders by laying out ambushes near the fortresses - a tactic which was later codified in the $10^{\text {th }}$ century de Velitatione. In short, it was Heraclius who introduced the standard East Roman defensive strategy and which consisted of the holding of the passes of the Taurus range

${ }^{40}$ Ṭabarī 2390-2391, $2393 f f$. 
or alternatively of the ambushing of the invaders when they were returning through these passes ${ }^{41}$.

\section{The Battle of Ajdanayn and the Muslim Conquest of Jerusalem in 635}

In the meanwhile, the Romans had assembled their remaining forces in the south at the cities of Skythopolis, Ajdanayn and Gaza. Two these cities, Skythopolis and Tiberias, surrendered on the same terms as Damascus, which meant that the Roman forces and all of those who wished departed with them. This gave the Muslims the possession of half of each city and its taxes. The terms of surrender enabled the Romans to evacuate their forces to the cities of Caesarea and Gaza. Gaza was held by al-Fiqar (vicarius), Caesarea by someone unknown, and Ajdanayn by al-Artabun (Artabanus). Umar ordered Amr to attack Artabanus, Alqamah b. Mujazziz to fight against vicarius and Yazid to send Muawiyah against Caesarea. Muawiyah defeated his enemy in battle and stormed and conquered his city. Alqmah b. Hakim al-Firasi and Masruq b. al-Akki were sent to isolate the defenders of Jerusalem so that these would be unable to bring help to the other cities. In addition to this Umar dispatched a relay of reinforcements to $\mathrm{Amr}^{42}$. Artabanus foiled the Muslim attempts for a long time simply by refusing to come out of his fortifications and trenches at Ajdanayn. He had also placed garrisons in the cities of Jerusalem and al-Ramlah. Amr, however, resorted to a stratagem. He acted as if he would be an envoy from Amr and entered the Roman fortifications to negotiate. When Amr had learnt what its weaknesses were, he returned back and attacked. Artabanus was defeated. The Muslim forces that were posted to guard Jerusalem gave way and allowed Artabanus to reach the city. These Muslims then joined Amr at Ajdanayn. Amr and Ubaydah wrote to Umar and asked his personal help on how to deal with the situation. Umar in his turn ordered the commanders to meet him at al-Jabiyah ${ }^{43}$.

When the news of the arrival of Umar was brought to Artabanus, he and al-Tadhariq fled to Egypt and abandoned the cities of Jerusalem and al-Ramlah to their own devices - both were subsequently killed during one of the summer raids. The populace decided to strike a deal with the Muslims. They realized that help would not be forthcoming anytime soon. Sophronios, the Bishop of Jerusalem, took the lead and asked for terms of surrender in return for religious freedom and the exclusion of Jews from the city of Jerusalem. Umar was a pragmatist and accepted this in return for the jizyah-tax payments by the Christian population. After this Umar entered the city of Jerusalem and started the building of the Dome of the Rock on the holiest of Jewish sites, the Temple Mount.

\footnotetext{
${ }^{41}$ Tabarī 2394-2396.

42 Ṭabarī 2158-2159, $2396 \mathrm{ff}$.

${ }^{43}$ Ṭabarī 2396ff.
} 


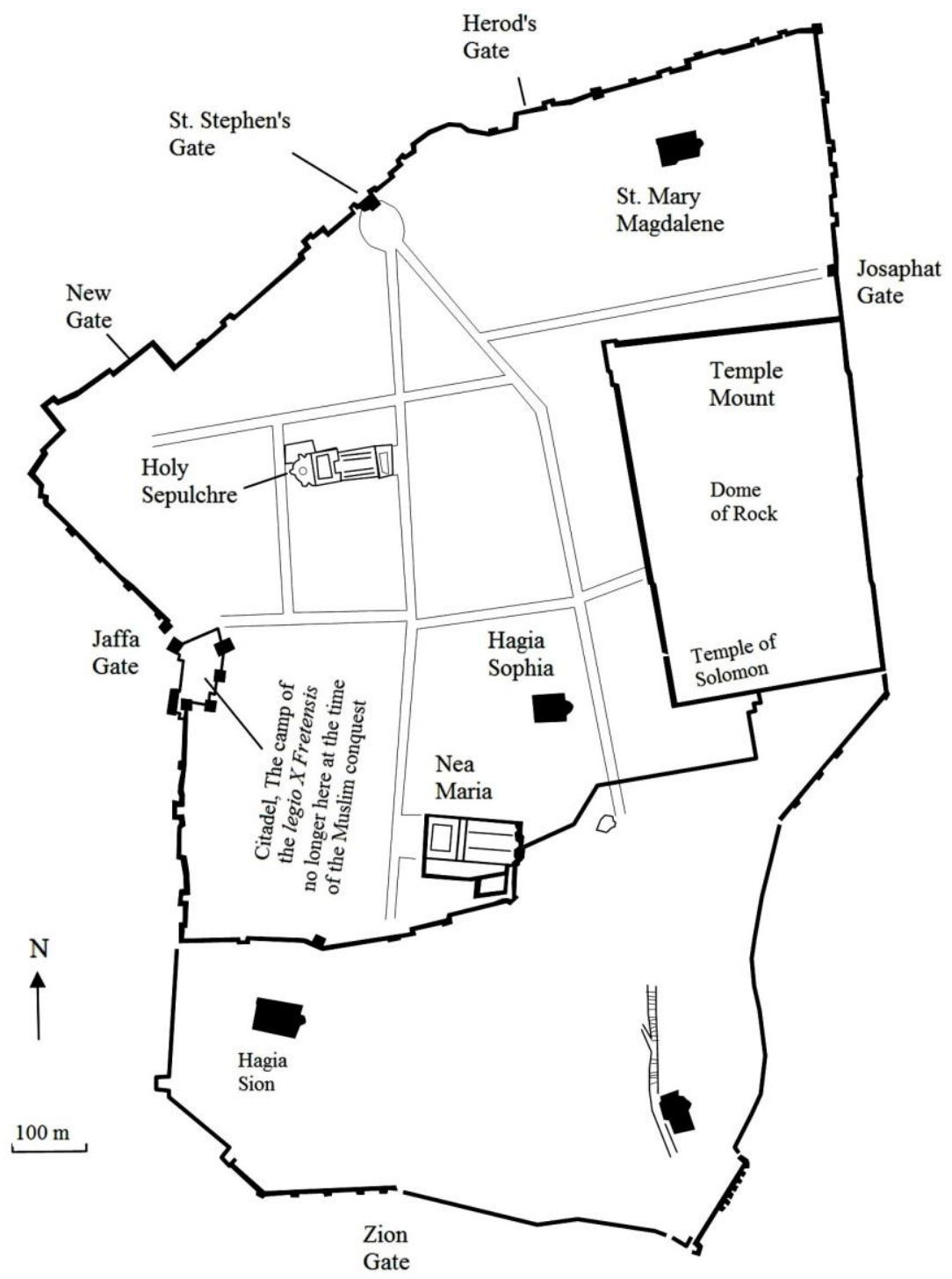

Fig. 7. Roman Jerusalem. C SYVÄNNE 2014

\section{Conclusions}

The Muslim conquest of Jerusalem was a military conquest. The Muslim claim to the city is entirely based on their original military conquest of the city in about 635-636. Had this attempt failed, there would not be any claim.

The principal reasons for the ability of the Muslims to capture Jerusalem were: 1) The Muslim use of the combined arms concept; 2) The inability of the Roman commanders to cooperate effectively and form any effective strategy to foil the Muslim 
advantages. In other words, the Romans committed the same mistake as the Persians when they fought against the Muslims ${ }^{44}$. This was a grave and militarily unforgivable mistake. The Roman reliance on cavalry worked quite well against the Sasanians, who also relied on cavalry to win their battles, but not against an enemy which employed the same combined arms concept as Alexander the Great had used. The Roman leadership also made the situation worse by choosing such battlefields that made retreat next to impossible. In contrast, the Muslim forces were always well drilled and under capable leaders. On top of this, unlike the Romans, the Muslims were at all times highly motivated to fight thanks to the religious indoctrination and string of successes they had enjoyed.

The account preserved by Tabarī - mainly after Sayf - has preserved for us the likeliest version of what happened during the initial stages of Muslim conquest. It is not only the most detailed of the accounts, but it is also the best match with the period fighting methods.

\section{Bibliography}

\section{Sources}

Das Strategikon des Maurikios, ed. G.T. DENNIS, tr. E. GAMILLSCHEG, Vienna 1981; Maurice's Strategikon, tr. G.T. DENNIS, Philadelphia 1984.

Histoire du texte d'Elien le Tacticien : des origines à la fin du Moyen âge, ed. A. DAIN, Paris 1946.

The Chronicle of Theophanes Confessor. Byzantine and Near Eastern History AD 284-813, eds. C. MANGO, R. SCOTT, G. GREATREX, Oxford 1997.

The History of al-Tabari Vol. 11: The Challenge to the Empires A.D. 633-635, ed. K.Y. BLANKINSHIP, New York 1993; The History of al-Tabari Vol. 12: The Battle of al-Qadisiyyah and the Conquest of Syria and Palestine A.D. 635-637, ed. Y. FRIEDMANN, New York 1992.

\section{Literature}

KAEGI W.E. (1992), Byzantium and early Islamic Conquests, Cambridge. KAEGI W.E. (2003), Heraclius Emperor of Byzantium, Cambridge.

SYVÄNNE I. (2004), The Age of Hippotoxotai, Tampere.

SYVÄNNE I. (2014), 'Persia, la caida de un imperio', Desperta Ferro 24, Julio.

SYVÄNNE I. (2015-2017), Military History of Late Rome, vols. 1-3, Barnsley.

${ }^{44}$ SYVÄNNE 2014. 